\title{
RESENHA. O DESAFIO DO CONHECIMENTO HISTÓRICO
}

\author{
REVIEW.O DESAFIO DO CONHECIMENTO HISTÓRICO
}

\section{RESEÑA. O DESAFIO DO CONHECIMENTO HISTÓRICO}

\author{
Vanusa Nascimento Sabino Neves \\ Universidade Federal da Paraíba, Brasil \\ https://orcid.org/0000-0001-6163-1699 \\ pbvanusa@gmail.com \\ Lia Machado Fiuza Fialho \\ Universidade Estadual do Ceará, Brasil \\ https://orcid.org/0000-0003-0393-9892 \\ lia_fialho@yahoo.com.br
}

Recebido: 18/09/2021 Revisado: 12/10/2021 Aceito:15/10/2021 Publicado: 16/10/2021

Autor: Rui Martinho Rodrigues

Editorial: EdUECE

Año: 2018

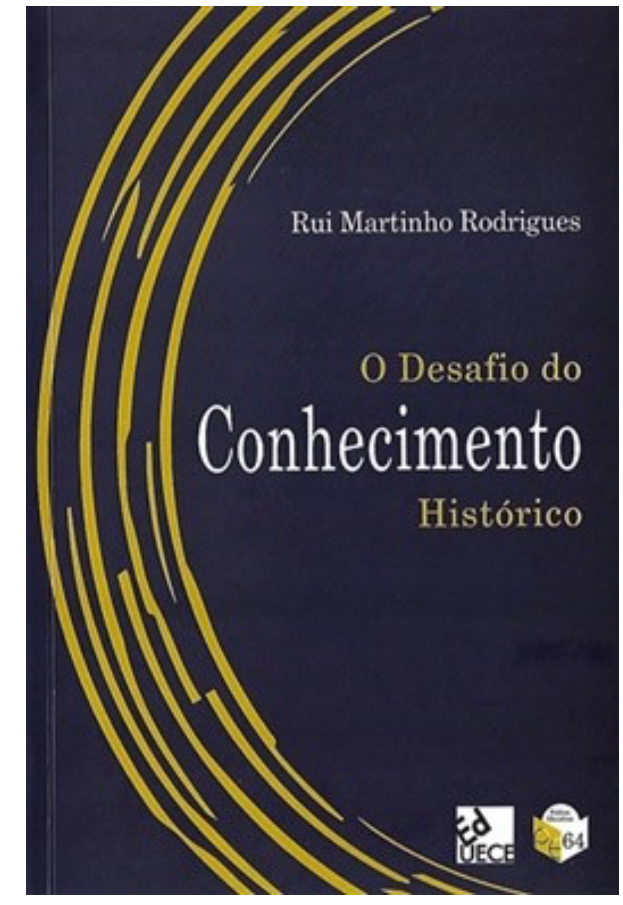

Como citar esta resenha: Neves, V.N.S., y Fialho, L.M.F. (2021). Revisão. O desafio do conhecimento histórico. Hachetetepé. Revista científica en Educación y Comunicación, (23), 13. https://doi.org/10.25267/Hachetetepe.2021.i23.2301

O livro se subdivide em três ensaios. O primeiro, intitulado "O saber e a ciência" (p. 15), discute a demarcação dos saberes e o desenvolvimento da ciência. O segundo, intitulado "História, conhecimento e educação: os saberes, a história, as fontes e a escola" (p. 85), relaciona conhecimento, educação e história aos conceitos de verdade. O terceiro, 
intitulado “C. S. Lewis, conhecimento, ceticismo e fé" (p. 104), centra ênfase na relação entre teologia e ciência segundo a perspectiva do teólogo escritor Clive Stapes Lewis.

De início, o intelectual é apresentado como produtor, intérprete, consumidor do saber e influenciador da História, cujas atividades, inclusive aquelas concernentes à sua ascensão social e à legitimação do poder, são instrumentalizadas pelo saber; mas, na demarcação desses saberes, observam-se diferentes gêneros que se diferenciam do senso comum e inspiram o perfil do cientista.

A gênese do conhecimento ocorre a partir de problemas "da tensão entre o saber e a ignorância" (p. 20). Existem diferentes categorias de ciência: a ciência normal, constituída pelo conjunto de saberes e crenças representantes do saber científico; e a ciência revolucionária, problematizadora dos seus próprios fundamentos e produtora de bruscas transformações científicas. Nesse âmbito, o senso comum demarca a ciência e a não ciência. Isso porque o senso comum é entendido como acrítico, imediatista, superficial e construído pela indução sobre repetidas observações. De outra maneira, a ciência é reputada como coerente, consistente, original, objetiva e validada por teorias.

A respeito do desenvolvimento da ciência, o livro relaciona as teorias do conhecimento ao vínculo sujeito-objeto. Desse modo, objetivistas são as teorias focalizadas nos objetos; as subjetivistas se centralizam nos sujeitos cognoscentes; e ainda existem aquelas que se concentram concomitantemente no sujeito e no objeto. Para escrutinar todas as complexidades da realidade e construir o saber científico, utilizam-se diversos métodos, como a dialética, a fenomenologia, a quantificação e o método hipotético-dedutivo.

Em linhas gerais, a dialética procura captar a completude do movimento histórico e suas contradições, mas os pesquisadores brasileiros têm se voltado para a "ciência normal", sem rupturas de paradigmas (p. 46). A fenomenologia questiona o positivismo e procura conhecer o real a partir do conhecimento da essência das experiências humanas. A quantificação implementa o simbolismo numérico nas ciências sociais por intermédio de processos quantitativos instrumentalizados por computadores, calculadoras, entre outros equipamentos. O método hipotético-indutivo procura explicar os fatos por meio da validação das proposições definidas a partir da observação da realidade.

Na segunda seção, o livro diferencia os saberes de acordo com o "animus do sujeito cognoscente", o objeto de estudo e os procedimentos de abordagem (p. 86). Nessa evolução, a "verdade sentida" (p. 87) é aquela captada pelas emoções peculiares às sociedades mais primitivas. A "verdade que nos é dita" (p. 89) valida-se ao se vincular à fonte produtora e, ainda hoje, é verificada em diversos âmbitos, até mesmo na literatura científica. A "verdade dos sentidos" (p. 91) aproxima-se do empirismo, perceptível através dos sentidos do organismo humano. A "verdade da razão" (p. 92) é desprovida de emoção e de volição, porquanto é determinada pela lógica. $\mathrm{O}$ "conhecimento segundo o seu objeto" (p. 93) é constituído conforme os objetos de investigação, práticos ou teóricos, a exemplo do que estuda a História Cultural, ou a História Social, e assim sucessivamente.

O status diferenciador dos saberes compreende quatro verdades, são elas: moral, objetiva, lógica e ontológica. Na moral, o pensamento e a ação humana estão em conformidade. Na objetiva, o pensamento corresponde ao objeto. $\mathrm{Na}$ lógica, objetos que não podem ser conhecidos em sua essência são excluídos e o pensamento concorda com as leis do pensamento. Na ontológica, a essência das coisas é expressa exatamente como é.

Outrossim, o livro correlaciona escola, História e difusão do saber por argumentar que, nas sociedades mais simples, a escola era despicienda e o processo educativo 
informal, mas o surgimento da escrita motivou o ensino. Para a História, a escrita é fulcral e o historiador, em sendo intérprete das fontes, sistematiza e propaga o conhecimento, conferindo significado às diversas experiências e fenômenos.

No último segmento, o livro problematiza a validação do conhecimento consoante o congraçamento teológico e filosófico de C. S. Lewis. Para tanto, discorre acerca da origem do saber segundo o empirismo e o racionalismo, retorna aos tipos e aos sentidos de verdade e coteja ciência e teologia.

Dentre os argumentos, exsurge que a verdade depende da confiança depositada na autoridade da fonte informante, tal qual um paciente confia no seu médico e o empreendedor no engenheiro da obra, mas as teorias carecem de validação plena, porque esta admite posicionamento em sentido contrário. O que não desqualifica a validade do conhecimento, porquanto não precisa ser verdadeiro", mas "apenas ser útil como modelo de explicação" (p. 115). Nos estudos teológicos, a verdade profética é a "verdade que nos é dita", cujo argumento de autoridade contém uma parcela de fé. Já o conhecimento atribuído aos profetas e aos videntes se associa à "verdade sentida", todavia, ao ser examinada em detalhes, revela-se susceptível a equívocos. A concepção racionalista defende a razão como intérprete da experiência e norteadora da observação sem o viés da ilusão. Tanto a confiança depositada na ciência como na teologia requisita fé; nesse quesito, ambas se equiparam.

Por derradeiro, destaca-se que o livro explana as nuances do pensamento de Lewis quanto às doutrinas teístas. Para mais, aduz que a teologia se expressa no discurso e, na polissemia da verdade, observam-se múltiplos sentidos: moral, objetivo, lógico e ontológico, sendo este último um dos campos da metafísica que se circunscreve na teologia. Igualmente, o termo "ideologia" é polissêmico, mas nem a ciência nem a filosofia estão isentas de ideologia, porém vitimar de desprezo o senso comum e supervalorizar o projeto de poder camuflado de ciência também é ideologia.

Diante da compreensão da obra, após análise crítica, infere-se que ao utilizar linguagem formal e objetiva, o autor transita por construtos relevantes interdisciplinarmente para os diversos campos científicos, incluindo o histórico, educacional e teológico, sem fácil compreensão para leitores leigos nessas temáticas.

No decorrer do texto, dialoga com o leitor mediante questionamentos geradores e modelos empíricos, levando-o a problematizar o assunto abordado. Também, ultrapassa o carácter descritivo e, de maneira fundamentada, evidencia as limitações dos métodos e das posturas investigativas ao denunciar o conservadorismo científico de intelectuais brasileiros, que não ousam em construir um conhecimento contra hegemônico aos paradigmas preestabelecidos, convocando-os a reorientar tal atitude.

\section{REFERÊNCIA BIBLIOGRÁFICA}

Rodrigues, R. M. (2018). O desafio do conhecimento histórico. EdUECE. 